\title{
The energy cost of standing and lying in adult cattle
}

\author{
BY J. E. VERCOE* \\ CSIRO Division of Animal Genetics, Cattle Research Laboratory, \\ Rockhampton, Qld 4700, Australia
}

(Received 22 August 1972-Accepied 27 February 1973)

\begin{abstract}
1. Gas exchanges on eleven steers with a mean weight of $273 \mathrm{~kg}$, fasted for $96 \mathrm{~h}$, were obtained over time intervals of $5.76 \mathrm{~min}$ in a confinement-type respiration chamber, when the animals were either standing or lying, or cngaged in the act of standing or lying.

2. In all, 75 $\mathrm{I}$ observations were analysed and these included twenty-four associated with the act of standing, forty-eight with the act of lying and the remainder approximately equally divided between standing and lying.

3. When lying, the heat production was $72 \cdot 2 \mathrm{~kJ}(\mathrm{I} 7 \cdot 2 \mathrm{kcal}) / \mathrm{kg}$ fasted weight per $24 \mathrm{~h}$ and when standing, $85.7 \mathrm{~kJ}$ (20.5 kcal) $/ \mathrm{kg}$ fasted weight per $24 \mathrm{~h}$; an increase when standing of $18.7 \%$. The double act of standing and lying was associated with an increase in heat production of $1 \mathrm{I} \cdot 3 \mathrm{~kJ}(2.7 \mathrm{kcal}) / 100 \mathrm{~kg}$ fasted weight and while the act of standing was energetically more costly than the act of lying, the difference between the two was not significant. 4. The results are discussed in relation to earlier estimates.

Confinement-type respiration chambers of the type described by Turner \& Thornton ( 1966 ), which have a fast response time and monitor the changes in chamber air frequently, are ideally suited to the detection of short-term changes in metabolic rate such as occur with changes in posture.
\end{abstract}

The two most widely quoted estimates of the energy cost of standing and lying in adult cattle (Forbes, Kris \& Braman, I927; Hall \& Brody, I933) were made either on a small number of animals using a very slow response instrument and technique, and based only on $\mathrm{CO}_{2}$ production, or using a mask technique under variable experimental conditions.

Since it is often necessary to correct metabolism values to standard conditions of standing and lying, because different bchavioural patterns in regard to standing and lying between individuals may be related to their fasting metabolism, results collected at this laboratory have been analysed to provide new estimates of the energy cost of standing, lying and the acts of standing and lying for adult cattle.

\section{EXPERIMENTAL}

In our confinement-type respiration chambers, described by Turner \& Thornton (1966), the partial pressures of oxygen, carbon dioxide and methane in the chamber air are measured, together with the dry-bulb temperature every $5 \cdot 76 \mathrm{~min}$; the time taken for a complete cycle of a I2-point (Speedomax G; Leeds and Northrup, Sydney, Australia) potentiometric recorder. The volumes of the various gases in the system can be calculated at each of these sampling times, and the mean rate of oxygen uptake and carbon dioxide and methane output for each time interval, calculated in $\mathrm{ml} / \mathrm{min}$. One chamber is fitted with a photoelectric cell connected to one channel of the recorder which indicates whether the animal is standing or lying. It was therefore

* Present address: Joint FAO/IAEA Division of Atomic Energy in Food and Agriculture, International Atomic Energy Agency, Vienna, Austria. 
possible to estimate from the results collected from this chamber the gas exchange associated with different postures.

For any given time interval of $5 \cdot 76 \mathrm{~min}$, one of the following six attitudes would be distinguished: (I) standing, (2) lying, (3) act of standing, (4) act of lying, (5) first interval after standing, or (6) first interval after lying. The gas exchange that occurred during each time interval was therefore assigned to a particular attitude.

The results analysed were collected from eleven steers after they had been fasted for $96 \mathrm{~h}$. The steers were crossbreeds of three basic breed-types (Hereford $\times$ Shorthorn, Brahman $\times$ Hereford $\times$ Shorthorn and Africander $\times$ Hereford $\times$ Shorthorn) and they varied in age ( $14^{-25}$ months) and fasted weight (194-334 kg; mean $273 \mathrm{~kg}$ ). The chamber temperature was from 27 to $30^{\circ}$. Measurements were made on the steers at different times. On two of the steers only one set of measurements was made, on five steers two sets of measurements, and on four steers three sets of measurements were made. Where possible, each set of measurements on a particular steer included all attitudes. In all, twenty-four sets of measurements. were available for analysis, a total of $75 \mathrm{r}$ observations (time intervals). Of these, twenty-four were associated with each of the attitudes 'act of standing' (3) and 'first interval after standing' (5), and forty-eight with each of the attitudes 'act of lying' (4) and 'first interval after lying' (6). The remaining observations were approximately evenly divided between the attitudes 'standing' ( 1 ) and 'lying' (2).

The results were non-orthogonal and the analysis was by the method of least squares (Harvey, 1960). The variance was partitioned into attitudes, blocks (sets of measurements regardless of animals), attitudes by blocks, and residual. Oxygen consumption and carbon dioxide production in $\mathrm{ml} / \mathrm{min}$ were analysed separately and the heat production was calculated from the mean values with the factors of Brouwer ( 1965$)$, ignoring the methane and urinary nitrogen. Heat production may therefore be slightly overestimated $(c .0 .8 \%)$ but the relative differences between attitudes were unlikely to be affected.

RESULTS

'The fitted values for attitudes are shown in Table $\mathrm{I}$ for oxygen consumption and carbon dioxide production, together with the differences between means necessary for significance $(P<0.05)$ and calculated heat productions. Attitudes were tested against the attitudes by blocks interaction and were significantly different $(P<0.01)$. The values for comparing the differences between means were based on the interaction mean square.

The results show that the oxygen consumption when standing was significantly higher than when lying and, though lower than for the act of standing, not significantly so. The oxygen consumption when lying was significantly less than for the act of standing or the act of lying. Similar results were found for carbon dioxide production. The fact that, for both oxygen and carbon dioxide, the measurements on the first interval after the acts of standing and lying were less than for the acts themselves and similar to the values for the subsequent intervals of standing or lying means that the change in gas exchange associated with these acts is transient. This also demcnstrates the short response time of the apparatus. 
Table I. Oxygen consumption and carbon dioxide production of steers and estimated heat production for standing, lying, act of standing and act of lying
Attitude
$\mathrm{O}_{2}$ consumption $\mathrm{CO}_{2}$ production
$(\mathrm{ml} / \mathrm{min}) \quad(\mathrm{ml} / \mathrm{min})$
Heat production

Standing ( $\mathrm{r}$ )

Lying (2)

Act of standing (3)

Act of lying (4)

$805 \quad 642$

$669 \quad 572$

572
688

$\begin{array}{ll}912 & 688 \\ 837 & 693\end{array}$

First interval after standing (5) $\quad 813 \quad 65 \mathrm{I}$

Second interval after lying (6)

674

570

$85 \cdot 70 \mathrm{~kJ}\left(20^{\circ} 48 \mathrm{kcal}\right) / \mathrm{kg}$ per $24 \mathrm{~h}$

$72 \cdot 23 \mathrm{~kJ}(\mathrm{I} 7 \cdot 26 \mathrm{kcal}) / \mathrm{kg}$ per $24 \mathrm{~h}$

I $\cdot 3 \mathrm{~kJ}(2 \cdot 7 \mathrm{kcal}) / \mathrm{roO} \mathrm{kg}$ for double act

Not significantly different from subsequent standing and lying periods respectively

Differences between means for significance

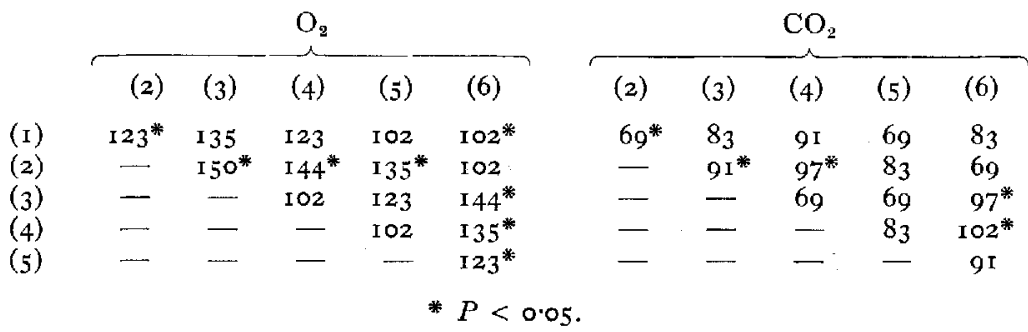

The heat production for standing was $18.7 \%$ higher than the lying value, and a standing steer expended $13.5 \mathrm{~kJ}(3.3 \mathrm{kcal}) / \mathrm{kg}$ fasted weight per $24 \mathrm{~h}$ more than a lying steer. More energy was expended in the act of standing than in the act of lying but the difference was not significant. It can be calculated from the results that the double movement from standing to lying and back to standing was associated with the expenditure of $30^{\circ} 5 \mathrm{~kJ}$ or I $13 \mathrm{~kJ}(2 \cdot 7 \mathrm{kcal}) / 100 \mathrm{~kg}$ live weight.

\section{DISCUSSION}

Hall \& Brody (1933) used a mask technique to estimate energy expenditure associated with standing and lying. Their estimates were made on beef and dairy cattle $8-\mathrm{i} 2 \mathrm{~h}$ after feeding ('resting' metabolism), and the increase in heat production associated with standing was expressed as a percentage of the lying 'resting' metabolism. Estimates varied from 7 to $13 \%$ but this value depends heavily on the lying 'resting' metabolism and would of course be higher if expressed as a percentage of the $96 \mathrm{~h}$ fasting metabolism. The value of Hall \& Brody (1933) can be recalculated (Blaxter, I962) to show that an additional $8.8 \mathrm{~kJ}(2 \cdot \mathrm{I} \mathrm{kcal}) / \mathrm{kg}$ body-weight per $24 \mathrm{~h}$ is expended when adult cattle stand. This value too would be higher if calculated for fasted weight to compare it with the present results. In fact, if it is assumed that adult cattle lose 12 \% of their weight when fasted for $96 \mathrm{~h}$ (Vercoe, unpublished), then the estimates of Hall \& Brody for the energy cost of standing become $10.0 \mathrm{~kJ}(2.4 \mathrm{kcal}) / \mathrm{kg}$ fasted weight per $24 \mathrm{~h}$.

Forbes et al. (1927) used their calorimeter as a respiration chamber and estimated heat production from $\mathrm{CO}_{2}$ production. Their estimate of the heat increment of standing was I I. $7 \mathrm{~kJ}(2.8 \mathrm{kcal}) / \mathrm{kg}$ body-weight per $24 \mathrm{~h}$. In this instance too the value, 
if expressed per $\mathrm{kg}$ fasted weight, would be raised to about $13.5 \mathrm{~kJ}(3.3 \mathrm{kcal}) / \mathrm{kg}$ fasted weight per $24 \mathrm{~h}$, a value similar to that from the present results. Colovos, Holter, Clark, Urban \& Hayes (1970), using a mask technique, produced an estimate of $16 \%$ for the heat increment of standing above that of lying, and more recently, from the same laboratory, Clark, Holter, Colovos \& Hayes (I972) estimated a value of $14.5 \%$.

Hall \& Brody (1933) estimated that the energy cost of the double act of standing and lying was about $10.5(2.5 \mathrm{kcal}) \mathrm{kJ} / \mathrm{r} 00 \mathrm{~kg}$ live weight and they stated that most of this cost was associated with the act of standing. Colovos et al. (1970) and Clark et al. (1972) estimated the cost of double act to be $32 \cdot 2$ and $26 \cdot 0 \mathrm{~kJ}(7 \cdot 7$ and $6 \cdot 2 \mathrm{kcal}) / \mathrm{roo} \mathrm{kg}$ weight respectively, but both these estimates are high because they were calculated from values expressed per unit metabolic weight, using a weight of $100 \mathrm{~kg}\left(100^{0.75}\right)$ instead of the mean weight $\left(\mathrm{W}^{0.75}\right)$. More correct estimates from their results are $2 \mathrm{I}^{\circ} 3$ and $17.6 \mathrm{~kJ}(5 . \mathrm{I}$ and $4.2 \mathrm{kcal}) / 100 \mathrm{~kg}$ weight respectively. In any event, their estimates were considerably higher than either that of Hall \& Brody (1933) or the present estimate of $\mathrm{II} \cdot 3 \mathrm{~kJ}(2 \cdot 7 \mathrm{kcal}) / 100 \mathrm{~kg}$ fasted weight. The reasons for these discrepancies are not known. However, in contrast to the statement of Hall \& Brody (r933), the results of the present work, and that of Colovos et al. (1970) and of Clark et al. (1972), indicate that a significant energy cost is involved in both the act of standing and of lying, although the cost of the act of standing is greater. The present estimate is based on relatively few observations and could have been influenced by the time at which the act of standing or lying occurred in a $5.76 \mathrm{~min}$ interval. However, the analysis indicates that neariy all of the change in gas exchange associated with the act of standing or lying is accounted for in the interval in which the act occurs, and it is unlikely that the estimate is more than $5-6 \%$ low on this account. The fact that the higher estimates of Colovos et al. (1970) and Clark et al. (1972) are derived from much heavier animals may be relevant; perhaps a heavier animal expends a greater amount of energy per roo kg weight in the act of standing or lying. This point is worthy of further investigation.

I thank Mr A. Day and Mrs C. Jones for assistance in the care of the animals and in the running of the respiration chambers, and Dr R. M. Seebeck for programme modifications to analyse the results.

\section{REFEREN CES}

Blaxter, K. L. (1962). The Energy Metabolism of Ruminants. London: Hutchinson. Brouwer, E. (1965). Publs Eur. Ass. Anim. Prod. no. I I, p. 44I.

Clark, R. MI., Holter, J. B., Colovos, N. F. \& Hayes, H. H. (1972). Y. Dairy Sci. 55, 257.

Colovos, N. F., Holter, J. B., Clark, R. M., Urban, W. E. \& Hayes, H. H. (r970). Publs. Eur. Ass. Anim. Prod. no. 13, p. 89.

Forbes, E. B., Kriss, M. \& Braman, W. W. (1927). 7. agric. Res. 35, 947.

Hall, W. C. \& Brody, S. (1933). Res. Bull. Ma. agric. Exp. Stn no. 180.

Harvey, W. R. (1960), U.S.D.A. Publ. no. ARS-zo-8.

Turner, H. G. \& Thornton, R. F. (1966). Proc. Aust. Soc. Anim. Prod. 6, 413. 